\title{
Biochemical and cellular biomarkers in brown trout (Salmo trutta f. fario) in response to the antidepressants citalopram and venlafaxine
}

\author{
Michael Ziegler ${ }^{{ }^{*}} \mathbb{0}$, Helene Eckstein ${ }^{1}$, Shannon Ottmann ${ }^{1}$, Lukas Reinelt ${ }^{1}$, Sabine Stepinski ${ }^{1}$, Heinz-R. Köhler ${ }^{1}$ \\ and Rita Triebskorn ${ }^{1,2}$
}

\begin{abstract}
Background: During the last decades, a worldwide increase in the number of cases of depression accompanied by rising prescription rates of antidepressants was recorded. In Germany, the two most prescribed antidepressants are the selective serotonin reuptake inhibitor (SSRI) citalopram and the serotonin and noradrenalin reuptake inhibitor (SNRI) venlafaxine, taking about 30\% of the market share. Both antidepressants are found frequently in surface waters and have the potential of adversely affecting aquatic organisms. Most studies dealing with antidepressants address apical endpoints and behaviour; however, only few studies investigate biochemical biomarkers and histopathological alterations. We conducted citalopram and venlafaxine exposure experiments over 5 months, starting with brown trout eggs in the eyed-ova stage, as well as with juvenile brown trout for 4 weeks. Exposure concentrations ranged from environmentally relevant $1 \mu \mathrm{g} / \mathrm{L}$ up to $1 \mathrm{mg} / \mathrm{L}$. In this study, we investigated the effects of the antidepressants on b-esterase activity (neurotoxicity), stress protein level (proteotoxicity) and superoxide dismutase activity (oxidative stress). Additionally, we assessed the health status of the liver by means of histopathological analyses.
\end{abstract}

Results: We were able to show that both antidepressants did neither induce proteotoxic nor neurotoxic effects in brown trout. But for venlafaxine, the biochemical biomarker for oxidative stress (superoxide dismutase activity) was significantly increased in larvae exposed to at least $10-\mu \mathrm{g} / \mathrm{L}$ venlafaxine at $7{ }^{\circ} \mathrm{C}$. With regard to liver histopathology, fish exposed to higher citalopram concentrations were in a worse health condition than control fish irrespective of their life stage. Also, the energy storage of fish exposed to $1 \mathrm{mg} / \mathrm{L}$ citalopram was reduced.

Conclusion: Thus, we here report citalopram-dependent histopathological alterations in brown trout liver, and the induction of oxidative stress by venlafaxine.

Keywords: Histopathology, Fish, B-esterase, Acetylcholinesterase, Superoxide dismutase, Hsp70, SNRI, SSRI

\section{Background}

Depression is one of the most common mental illnesses worldwide and has undergone a continuous increase during the last decades $[1,2]$. Worldwide, the number

\footnotetext{
*Correspondence: michael.ziegler@student.uni-tuebingen.de ${ }^{1}$ Animal Physiological Ecology, University of Tübingen, Auf der Morgenstelle 5, 72076 Tübingen, Germany

Full list of author information is available at the end of the article
}

of cases of depression showed an increase of about $50 \%$ since 1990 [1]. Associated with an increasing number of cases of depression, the number of prescribed antidepressants is constantly rising. In Germany, prescription rates of antidepressants increased about $40 \%$ between 2009 and 2018 [3]. Selective serotonin reuptake inhibitors (SSRI) and serotonin and noradrenalin reuptake inhibitors (SNRI) constitute the majority of antidepressants. Two of the most prescribed antidepressants 
worldwide are citalopram (SSRI) and venlafaxine (SNRI). They amount to about $30 \%$ of the market share in Germany [3]. This leads to a total consumption of 4.5 $\mathrm{t}$ (262.3 million defined daily doses (DDD)) of citalopram and $20.5 \mathrm{t}$ (205.4 million DDD) of venlafaxine in 2018 in Germany only [3]. Both antidepressants affect a similar biochemical pathway by inhibiting the reuptake of neurotransmitters from the synaptic cleft. Due to this, citalopram increases the serotonin level and venlafaxine the serotonin and noradrenaline level in the synaptic cleft $[4,5]$. Both are known to be metabolised in liver and kidney of the human body. However, $12-23 \%$ of citalopram and $4.7-10 \%$ of venlafaxine are excreted unmetabolised via the urine and, therefore, enter wastewater treatment plants [4-8]. There, $18-27 \%$ of the citalopram is degraded, while the degradation of venlafaxine is even less efficient, amounting to $1-19 \%[9,10]$. Therefore, both antidepressants are found frequently in surface waters around the world [11-17]. Citalopram surface water concentrations commonly range from $4 \mathrm{ng} / \mathrm{L}$ to $219 \mathrm{ng} / \mathrm{L}[16,17]$ but, occasionally, also concentrations of up to $8 \mu \mathrm{g} / \mathrm{L}$ have been found in Indian lakes [12]. Concentrations of citalopram in wastewater treatment plant effluents are usually in the range of $44 \mathrm{ng} / \mathrm{L}-431 \mathrm{ng} / \mathrm{L}[14,16,18]$, but exceptional high concentrations up to $76-\mu \mathrm{g} / \mathrm{L}$ citalopram was found downstream of an Indian wastewater treatment plant, and up to $840 \mu \mathrm{g} / \mathrm{L}$ in the effluent of an Indian drug manufacturer [12, 19]. Venlafaxine concentrations in surface waters are higher than those for citalopram and range between 8 and $690 \mathrm{ng} / \mathrm{L}$ in wastewater-dominated streams $[11,13,14]$. Moreover, up to $2.5-\mu \mathrm{g} / \mathrm{L}$ venlafaxine was found in wastewater effluents [10]. Being detected in such high concentrations, the effects of antidepressants, particularly of venlafaxine and citalopram, on aquatic life are important to being investigated. For both antidepressants, most studies were conducted regarding behavioural and apical endpoints in several fish species [20, 21]. Behavioural changes in fish following exposure to venlafaxine or citalopram include changes in circadian rhythm [22], decreased escape behaviour [23], reduced attacks on food [24], changes in swimming behaviour [25, 26] and increased curiosity [27]. With regard to biochemical or structural biomarkers, however, knowledge about possible effects of citalopram and venlafaxine in fish is scarce [28-31]. While venlafaxine did not affect the activity of the enzymes citrate synthase, catalase and pyruvate kinase in zebrafish, effects on superoxide dismutase (SOD) and acetylcholine esterase activities and the heat shock response were detected in fish exposed to different antidepressants [28, 30,31]. With respect to possible histopathological consequences in fish, different results have been reported. Fathead minnow exposed to either venlafaxine, fluoxetine or sertraline did not reveal any histological effects in liver [29], while zebrafish and Chichlosoma dimerus exposed to fluoxetine, sertraline, paroxetine or mianserine showed histopathological alterations in liver, spleen and head kidney [32, 33]. Thus, no consistent picture of possible effects of these pharmaceuticals on suborganismic effects in aquatic species can be drawn. In addition, data on the interplay of antidepressants and the confounding factor temperature are lacking up to now, and potential variation in the sensitivity of different life stages of fish has not been investigated so far. Consequently, we conducted experiments with brown trout (Salmo trutta f. fario), a feral fish species at different life stages at two temperatures. Brown trout are a sensitive monitoring organism with a high ecological relevance in Central Europe [34, 35]. Eggs in the eyed-ova stage and juvenile fish were exposed to environmentally relevant and explicitly higher concentrations of the antidepressants citalopram and venlafaxine with focus on neurotoxicity (b-esterase activity), oxidative stress (SOD activity), proteotoxicity (stress protein level) and liver histopathology (overall health condition).

B-esterases, including acetylcholinesterase and carboxylesterases among others, are enzymes that are inhibited by paraxon [36, 37]. Acetylcholinesterase (AChE) is an enzyme present in the synaptic cleft of cholinergic synapses, hydrolysing the neurotransmitter acetylcholine into its subcomponents acetic acid and choline [38]. $\mathrm{AChE}$ is inhibited by various substances, such as carbamates or organophosphates and, thus, their inhibition can be seen as an adequate biomarker for neurotoxicity [30]. Carboxylesterases (CbE) are known to detoxify insecticides like organophosphates, carbamates or pyrethroids and protectively counteract organophosphateinduced acetylcholinesterase inhibition [39, 40]. It has already been shown that antidepressants like citalopram, fluoxetine or sertraline affect acetylcholinesterase activity in aquatic organisms [30, 41, 42].

Superoxide dismutase (SOD) is an enzyme of the first line of the antioxidant defence system that catalyzes the dismutation of $\mathrm{O}_{2}{ }^{-}$radicals to hydrogen peroxide $\left(\mathrm{H}_{2} \mathrm{O}_{2}\right)$. This compound can subsequently be decomposed to water and oxygen, catalyzed by the enzyme catalase [30, 43]. Reactive oxygen species (ROS) are formed in several biological reactions; however, they can also be induced by xenobiotics [44]. These ROS including superoxide radicals $\left(\mathrm{O}_{2}{ }^{-}\right)$are known to react with proteins, DNA and lipids resulting in oxidative stress for the organism [45]. Therefore, an increased SOD activity is accompanied by an increased amount of ROS and, thus, represents an appropriate biomarker for oxidative stress [46]. An 
increased SOD activity has been shown in amitriptylineexposed zebrafish [31], sertraline-exposed goldfish [30], venlafaxine-exposed meagre (Argyrosomus regius) [28] and citalopram-exposed daphnids [42].

Stress proteins or heat shock proteins with $70-\mathrm{kDa}$ molecular weight (Hsp70) are chaperones, that bind to unfold, malfold or newly synthesised proteins to assist correct folding to the native protein [47, 48]. These Hsp70s are induced by an increased portion of malfolded proteins in the cytoplasm and their induction is, therefore, regarded as a suitable biomarker for proteotoxicity [49]. Maulvault, et al. [28] have shown an elevated heat shock protein response and ubiquitin level in meagre exposed to venlafaxine.

The liver is the main metabolic organ of vertebrates and is responsible for many vital functions like the metabolism of proteins, lipids and carbohydrates, as well as the detoxification of xenobiotics [50]. Therefore, histopathological investigation of the liver is a powerful tool to assess sublethal effects of xenobiotics in fish [51-53]. In zebrafish exposed to the antidepressants sertraline, paroxetine or mianserine, a reduced proliferation of liver hepatocytes has been detected [32]. Changes in liverassociated macrophage centres were shown in fluoxetineexposed Chichlosoma dimerus [33].

The present study has been designed to complement existing data on citalopram and venlafaxine toxicity exerted on freshwater organisms, particularly with respect to biochemical and cytological effects of these two compounds. Therefore, we hypothesise that the antidepressants citalopram and venlafaxine alter enzyme activity and change the histological structure in the liver, resulting in health impairment of the fish. Behavioural and apical endpoints that, furthermore, have been investigated in our experiments have been previously published $[54,55]$.

\section{Materials and methods Test organisms}

Juvenile brown trout and brown trout eggs were purchased from a commercial trout farm in Southern Germany (Forellenzucht Lohmühle, Alpirsbach-Ehlenbogen, Germany). This commercial fish breeder is listed as disease free (category I) according to the EC Council Directive [56]. The eggs were obtained in the eyed-ova stage and directly transferred into the experiments. Experiments with brown trout larvae took place in two climate chambers set on $7{ }^{\circ} \mathrm{C}$ or $11^{\circ} \mathrm{C}$, respectively, with a 10:14-h light-dark-cycle. Prior to the experiments, juvenile brown trout were kept in an acclimation tank for at least 1 week. Experiments with juvenile brown trout were carried out in a climate chamber at $7{ }^{\circ} \mathrm{C}$ and the same photoperiod. All animal experiments were approved by the animal welfare committee of the Regional Council of Tübingen, Germany (ZO 2/16).

\section{Test substances}

Citalopram hydrobromide $\left(\mathrm{C}_{20} \mathrm{H}_{21} \mathrm{FN}_{2} \mathrm{O} \cdots \mathrm{HBr}\right.$, CAS: 59729-32-7) and venlafaxine hydrochloride $\left(\mathrm{C}_{17} \mathrm{H}_{27} \mathrm{NO}_{2} \cdots \mathrm{HCl}\right.$, CAS: $\left.99300-78-4\right)$ were obtained by Sigma Aldrich (Steinheim, Germany). Citalopram and venlafaxine stock solutions with concentrations of 1 and $100 \mathrm{mg} / \mathrm{L}$ were prepared with double distilled water and diluted to the respective test concentrations with filtered tap water (iron filter, active charcoal filter, particle filter). The concentrations refer to the respective free base substance (citalopram: $\mathrm{C}_{20} \mathrm{H}_{21} \mathrm{FN}_{2} \mathrm{O}$; venlafaxine: $\mathrm{C}_{17} \mathrm{H}_{27} \mathrm{NO}_{2}$ ).

\section{Exposure conditions}

In both experiments, measured chemical concentrations only differed slightly from nominal concentrations by $16 \%$ for venlafaxine and $19 \%$ for citalopram on the average, and limnochemical analyses revealed optimal test conditions with respect to temperature $\left( \pm 1.5^{\circ} \mathrm{C}\right)$, oxygen content (>90\%), $\mathrm{pH}[4,20,57]$ and conductivity $(450-525$ $\mu \mathrm{S} / \mathrm{cm})$. Detailed data can be taken from $[54,55]$.

\section{Experiments with brown trout larvae}

As described previously $[54,55]$, the eyed-ova staged eggs of brown trout were exposed in a semi-static randomised three-block design at $7{ }^{\circ} \mathrm{C}$ and $11{ }^{\circ} \mathrm{C}$. The respective nominal exposure concentrations of either citalopram or venlafaxine were $0,1,10,100,1000 \mu \mathrm{g} / \mathrm{L}$. Fish were exposed in $25-\mathrm{L}$ aquaria containing $10 \mathrm{~L}$ of the respective test solution, half of which was renewed twice a week. From the total yolk sac consumption until the end of the experiment, fish were fed daily $3 \%$ of body weight with commercial trout feed (first $0.5 \mathrm{~mm}$, then $0.8 \mathrm{~mm}$, Inico Plus, Biomar, Brande, Denmark). Fish were exposed until eight respectively seven weeks after yolk sac consumption in the citalopram $\left(7^{\circ} \mathrm{C}: 135\right.$ days, $11^{\circ} \mathrm{C}$ : 107 days) respectively venlafaxine experiment $\left(7{ }^{\circ} \mathrm{C}\right.$ : 128 days, $11^{\circ} \mathrm{C}: 105$ days). At the end of the experiments, fish were euthanised with an overdose of the anaesthetic MS222 (1 g/L tricaine methanesulphonate buffered with $\mathrm{NaHCO}_{3}$ ), followed by a cervical spine cut. Subsequently, fish were dissected. Livers were used for histopathology, heads for analyses of the b-esterase activity and the dorsal body part containing muscle, kidney and spinal cord for testing superoxide dismutase activity (only for the venlafaxine experiment). Livers were directly fixed in $2 \%$ glutardialdehyde (GA) dissolved from $25 \%$ GA with cacodylic buffer $(0.1 \mathrm{M}, \mathrm{pH} 7.6)$ and stored at $4{ }^{\circ} \mathrm{C}$ until further processing. Samples for superoxide dismutase activity analysis were rinsed in PBS buffer ( $\mathrm{pH}$ 7.4), and, 
along with the samples taken for b-esterase activity, frozen in liquid nitrogen and stored at $-80^{\circ} \mathrm{C}$.

\section{Experiments with juvenile brown trout}

As described in previous publications [54, 55], juvenile brown trout were exposed to $0,1,10,100$ and $1000 \mu \mathrm{g} / \mathrm{L}$ of either citalopram or venlafaxine at $7^{\circ} \mathrm{C}$ in a semistatic randomised block design with three replicates. Ten fish were exposed in 25-L tanks containing $15 \mathrm{~L}$ of the respective concentrations. Twice a week, half of the respective test solution was replaced by freshly prepared test medium. Trout were fed $3 \%$ of body weight daily (0.8 mm, Inico Plus, Biomar, Brande, Denmark). After approximately 4 weeks of exposure (citalopram experiment: 28 days, venlafaxine experiment: 25 days), fish were euthanised with an overdose of MS222 (1 g/L buffered with $\mathrm{NaHCO}_{3}$ ) followed by a cervical spine cut. Samples were taken from the liver for histopathological analyses, the head was used for analyses of b-esterase activity, the dorsal part of the body containing mainly muscle and kidney was taken for superoxide dismutase testing (only venlafaxine experiment), and the gills were used for stress protein analysis. Liver samples were directly fixed in $2 \%$ glutardialdehyde (GA) dissolved from $25 \%$ GA with cacodylic buffer (0.1 M, pH 7.6) and stored at $4{ }^{\circ} \mathrm{C}$. Samples for superoxide dismutase activity were rinsed in PBS buffer ( $\mathrm{pH} 7.4)$ and, along with samples for the other biochemical biomarkers, frozen in liquid nitrogen and stored at $-80{ }^{\circ} \mathrm{C}$.

\section{Histopathology}

After at least 1 week of fixation, samples were washed three times with cacodylic buffer (0.1 M, pH 7.6), dehydrated in an ascending ethanol series, followed by 2-propanolol as an intermedium and infiltrated with paraffin wax in a tissue processor (TP 1020, Leica, Wetzlar, Germany). Afterwards, 3- $\mu$ m sections were cut with a sledge microtome (SM 2000 R, Leica, Wetzlar, Germany). One of the microscope slides was stained with haematoxylin-eosin as an overview staining, and every other slide with alcian blue in combination with periodic acid-Schiff reagent (alcian blue-PAS) as a stain for glycogen and mucopolysaccharides. Slides were visually analysed using observer-blinded assessment. The second evaluation was semi-quantitative, in which samples were classified into five different categories (1-control, 2-slight reaction, 3-moderate reaction, 4-strong reaction, 5-destruction) according to the criteria described by Triebskorn, et al. [58]. Additionally, the glycogen content of the samples was classified into three categories (1-low, 2medium, 3-high glycogen content).

\section{Biochemical biomarkers \\ Superoxide dismutase activity}

Superoxide dismutase (SOD) activity was measured in venlafaxine-exposed fish only, using the superoxide dismutase assay kit by Cayman Chemical (Item No. 706002, Cayman Chemical Company, Ann Arbor, Michigan, USA). Tissues were homogenised in HEPES buffer (20 mM HEPES, 1 mM EGTA, 210 mM mannitol, 70 mM sucrose, $\mathrm{pH} 7.2$, tissue/buffer ratio $1: 5 \mathrm{w} / \mathrm{v})$ with a pestle, and subsequently centrifuged $\left(1500 \times g, 5 \mathrm{~min}, 4^{\circ} \mathrm{C}\right)$. After centrifugation, the supernatant was taken, mixed with Tris-HCl buffer (50 mM, pH 8) (supernatant/buffer ratio $1: 30 \mathrm{w} / \mathrm{v}$ ) and stored at $-80{ }^{\circ} \mathrm{C}$. Before performing the assay, the radical detector solution was freshly prepared from 19.95-mL assay buffer (50-mM Tris- $\mathrm{HCl}$, 0.1-mM DTPA, 0.1-mM Hypoxanthine) and 50- $\mu \mathrm{L}$ tetrazolium salt solution (Item No. 706004, Cayman Chemical Company, Ann Arbor, Michigan, USA). Additionally, the SOD-standard curve $(0,0.005,0.01,0.02,0.03,0.04$, 0.05 SOD activity $(\mathrm{U} / \mathrm{mL})$ ) was freshly prepared containing bovine erythrocyte SOD (Item No. 706005, Cayman Chemical Company, Ann Arbor, Michigan, USA). The assay was performed in 96-well plates with each well being filled with $200-\mu \mathrm{L}$ radical detector. In the first wells, $10 \mu \mathrm{L}$ of the standard and in the remaining wells, $10 \mu \mathrm{L}$ sample was pipetted in duplicates. Subsequently, 50- $\mu \mathrm{L}$ xanthine oxidase (Item No. 706006, Cayman Chemical Company, Ann Arbor, Michigan, USA) was mixed with $1.95-\mathrm{mL}$ assay buffer. $20 \mu \mathrm{L}$ of this solution was given in each well; the plate was sealed with adhesive foil and incubated for $30 \mathrm{~min}$ at room temperature. Subsequently, the plate was measured photometrically at $450 \mathrm{~nm}$ and the SOD activity was calculated according to the following equation:

$$
\left[\left(\frac{\text { sample linearised rate }-y \text { intercept }}{\text { slope }}\right) *\left(\frac{0.23 \mathrm{ml}}{0.01 \mathrm{ml}}\right)\right] * \text { sample dilution. }
$$

a light microscope (Axioskop 2, Zeiss, Oberkochen, Germany). A first evaluation of all samples was conducted to get an overview and to qualitatively assess occurring pathological changes. In a second round, samples were re-labelled in a randomised order to obtain an
Results are expressed as unit $(\mathrm{U}) / \mathrm{mL}$. One unit is defined as the amount of enzyme needed to exhibit $50 \%$ of the superoxide radical. 


\section{B-esterase activity}

For measuring the b-esterase activity, fish head samples were homogenised manually in Tris-buffer (10$\mathrm{mM}$ Tris, $10-\mathrm{mM} \mathrm{NaCl}, \mathrm{pH}$ 7.3) mixed with protease inhibitors (aprotinin, leupeptin, pepstatin, antipain, trypsin). After homogenisation, samples were centrifuged $\left(5000 \times g, 10 \mathrm{~min}, 4{ }^{\circ} \mathrm{C}\right)$, the supernatant was taken and $10 \%$ glycerol was added before storage at $-20{ }^{\circ} \mathrm{C}$. The protein content of the samples was determined photometrically at $650 \mathrm{~nm}$ according to the method of Lowry, et al. [59], modified by Markwell et al. [60]. Bovine serum albumin was used as a standard. The determination of the acetylcholinesterase (AChE) activity was conducted according to Ellman et al. [61], modified by Rault et al. [38] and measured for $5 \mathrm{~min}$ at $405 \mathrm{~nm}$. This method has some disadvantages [62] but was used because of the convenient usage. The activity of the carboxylesterases $(\mathrm{CbE})$ was analysed using the substrates 4-nitrophenylacetate (NPA) and 4-nitrophenylvalerate (NPV). Determination was conducted according to Carr and Chambers [39] and Chanda et al. [63], modified by Sanchez-Hernandez et al. [40]. The activity was also measured for $5 \mathrm{~min}$ at $405 \mathrm{~nm}$. All samples were analysed in triplicates. The activity of AChE and CbE is referred to the protein content and expressed as milliunits $(\mathrm{mU}) / \mathrm{mg}$ protein. One unit is defined as one micromole of substrate hydrolysed per minute.

\section{Stress protein level}

The quantification of $70-\mathrm{kDa}$ stress proteins (Hsp70) was conducted in gill samples of the juvenile fish. Samples for larvae were not analysed in this assay due to the low weight of the samples and the high base loads of stress proteins in developing brown trout [64]. Gills were homogenised with $98 \%$ of extraction buffer and $2 \%$ protease inhibitor (tissue/buffer ratio $1: 4 \mathrm{w} / \mathrm{v}$ ) according to the protocol of Dieterich et al. [65]. The total protein content was quantified according to Bradford [57]. For the quantification of Hsp70, a total amount of $40 \mu \mathrm{g}$ total protein was analysed. The proteins were separated by sodium dodecyl sulphate polyacrylamide gel electrophoresis (SDS-PAGE) and subsequently blotted on a nitrocellulose membrane in a semi-dry chamber according to Dieterich, et al. [65]. Subsequently, the protein bands on the membrane were immunostained with a monoclonal $\alpha$-Hsp70 IgG (mouse anti-human Hsp70, Dianova, Hamburg, Germany) and secondary peroxidase-coupled $\alpha$-IgG (goat anti-mouse IgG conjugated to peroxidase, Jackson Immunoresearch, West Grove, Pennsylvania, USA). Subsequently, membranes were stained with 4-chloro-1-naphthol until the protein bands became visible. Finally, the optical volume (= band area $\times$ average grey scale value) of the bands was quantified by planimetry and densitometry and referred to an internal standard (brown trout total body homogenate). Results are expressed relative to the standard.

\section{Statistics}

Statistical analyses were performed with SAS JMP 14 software. Data for histological evaluation, either pathological classes or glycogen classes, were analysed with the likelihood-ratio $X^{2}$ test. Whenever significant differences occurred, single comparisons between control and each treatment were also performed with the likelihoodratio $\chi^{2}$ test. To correct for multiple comparisons, the $\alpha$-level was adjusted according to the method developed by Benjamini and Hochberg [66]. Data for biochemical biomarkers were analysed using a nested ANOVA with a subsequent post hoc Dunnett's test. If necessary, data were transformed to fulfil model assumptions. If no normal distribution could be achieved by transformation, data were analysed using a Kruskal-Wallis test with subsequent post hoc Steel with control. If no homogeneity of variance was given, data were analysed using a Welch ANOVA with subsequent post hoc Dunnett's test. The $\alpha$-level was always set to 0.05 .

\section{CRED}

Criteria for reporting and evaluating ecotoxicity data (CRED) aim to improve the evaluation, transparency, reproducibility and consistency of reliability of ecotoxicological studies. For the experiment with citalopram CRED were previously published and provided by Ziegler et al. [54] and, for the experiments with venlafaxine, CRED are provided in Ziegler et al. [55].

\section{Results}

\section{Histopathology}

Generally, the health status of the liver was negatively affected by an exposure in the experimental setup.

In the citalopram experiments, livers of the control and the 1 and $10 \mu \mathrm{g} / \mathrm{L}$-exposed animals were characterised by large hepatocytes with a bright cytoplasm (Fig. 1a). In contrast, brown trout exposed to 100- and $1000-\mu \mathrm{g} / \mathrm{L}$ citalopram had darker cells and regularly showed hyperplasia of hepatocytes (Fig. 1c). In livers of fish exposed to $1000-\mu \mathrm{g} / \mathrm{L}$ citalopram, inflammations occurred more frequently (Fig. 1b). Additionally, livers of fish exposed to the highest treatment showed reduced glycogen contents compared to the control fish (Fig. 1d, e). In juvenile fish treated with 100- or 1000$\mu \mathrm{g} / \mathrm{L}$ citalopram, vacuolisation was more pronounced 

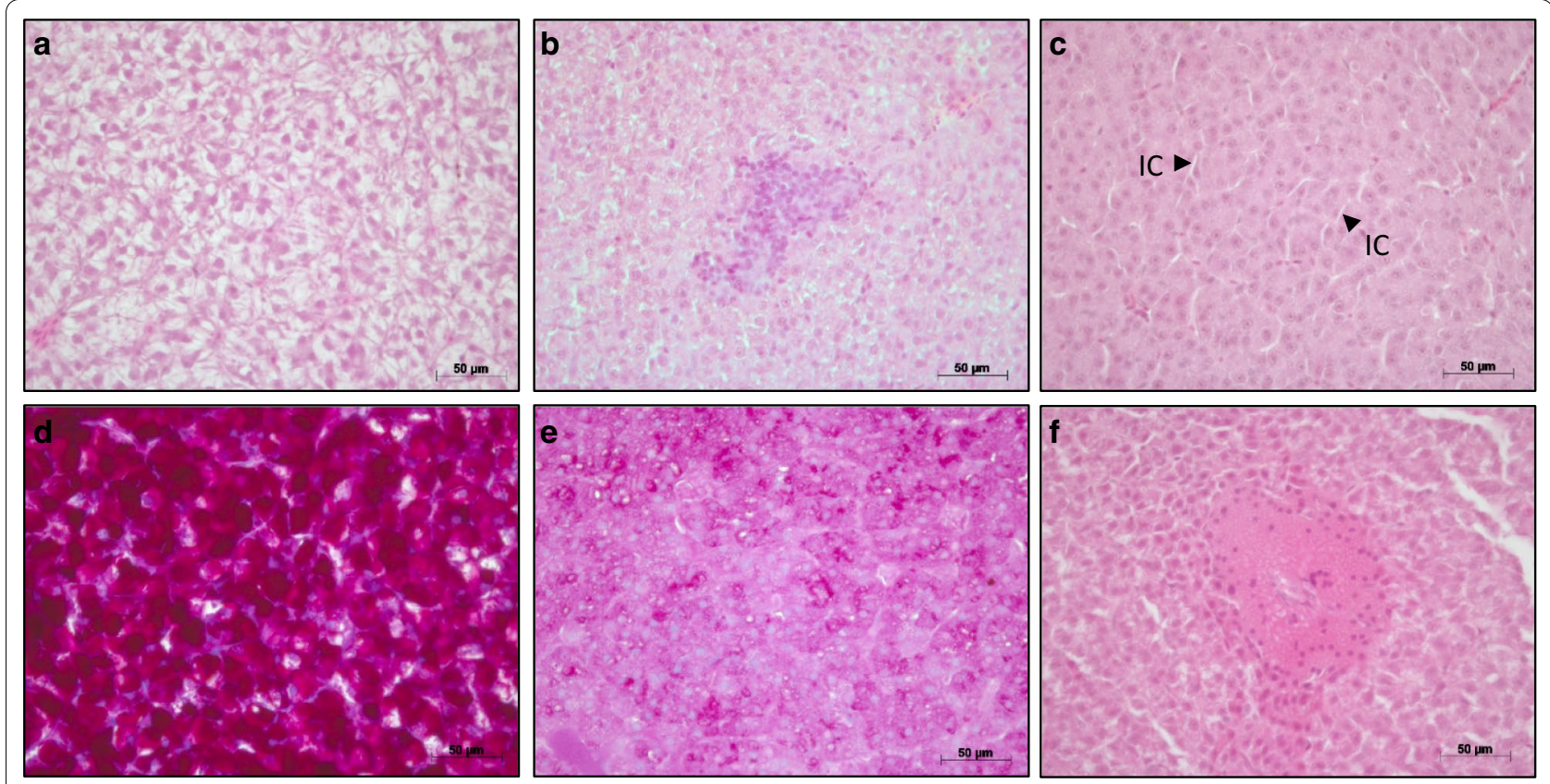

Fig. 1 Histological status of brown trout livers: a control status, HE-stain, b reaction status: inflammation, HE-stain, c reaction status: smaller and darker hepatocytes with extended intercellular spaces (IC), HE-stain, $\mathbf{d}$ high glycogen content in the liver of control fish, alcian-blue-PAS-stain, e low glycogen content, alcian-blue-PAS-stain, $\mathbf{f}$ destruction status: necrosis, HE-stain. All pictures show livers of brown trout larvae, but also represent adequately the depicted pathological changes in juvenile fish

than in the controls. In all treatments, dilated capillaries, necrosis and macrophages occurred (Fig. 1c, f). When comparing the overall health status of the larvae, those animals exposed at $11^{\circ} \mathrm{C}$ generally were in a worse condition than fish exposed at $7{ }^{\circ} \mathrm{C}$. Livers of larvae exposed to $1000-\mu \mathrm{g} / \mathrm{L}$ citalopram at $11^{\circ} \mathrm{C}$ and those exposed to $100-\mu \mathrm{g} / \mathrm{L}$ citalopram at $7{ }^{\circ} \mathrm{C}$, as well as juvenile brown trout exposed to $1000-\mu \mathrm{g} / \mathrm{L}$ citalopram were in a significantly worse condition than livers of control fish (Fig. $2 \mathrm{a}-\mathrm{c}$ ) (brown trout larvae $11^{\circ} \mathrm{C}$ : likelihood-ratio $\chi^{2}$ test: $d f=16, \chi^{2}=30.986, p=0.0135$, pairwise comparison [control $\mid 1000 \mu \mathrm{g} / \mathrm{L}] p=0.0036$; brown trout larvae $7{ }^{\circ} \mathrm{C}$ : likelihood-ratio $X^{2}$ test: $d f=16, \chi^{2}=40.467, p=0.0007$, pairwise comparison [control|1000 $\mu \mathrm{g} / \mathrm{L}] \quad p=0.0047$; juvenile brown trout: likelihood-ratio $\chi^{2}$ test: $d f=16, \chi^{2}=30.706, p=0.0147$, pairwise comparison [control|1000 $\mu \mathrm{g} / \mathrm{L}$ ] $p=0.0095$ ). Furthermore, brown trout larvae treated with 1000$\mu \mathrm{g} / \mathrm{L}$ citalopram had a significantly decreased glycogen content when exposed at $11{ }^{\circ} \mathrm{C}$ (Fig. 2d) (brown trout larvae $11{ }^{\circ} \mathrm{C}$ : likelihood-ratio $\chi^{2}$ test: $d f=8, \chi^{2}=48.951$, $p<0.0001$, pairwise comparison [control|1000 $\mu \mathrm{g} / \mathrm{L}$ ] $p=0.0008$ ). Both, brown trout larvae exposed to $1000 \mu \mathrm{g} / \mathrm{L}$ at $7{ }^{\circ} \mathrm{C}$ and juvenile brown trout exposed to $1000 \mu \mathrm{g} / \mathrm{L}$ had tendentially a lower glycogen content than the control (Fig. 2e, f). However, this effect was not significant (brown trout larvae $7{ }^{\circ} \mathrm{C}$ : likelihoodratio $\chi^{2}$ test: $d f=8, \chi^{2}=19.807, p=0.0111$, pairwise comparison revealed no difference to control; juvenile brown trout: likelihood-ratio $x^{2}$ test: $d f=8, \chi^{2}=8.804$, $p=0.3591$ ). Generally, the glycogen content appeared to be lower in juvenile brown trout than in brown trout larvae. With regard to the liver condition, however, no distinct differences between larvae and juveniles were observed (Fig. 3).

After exposure to venlafaxine as well as in control fish larvae, livers were characterised by large hepatocytes with a bright cytoplasm (Fig. 1a). Throughout all treatment groups at $11{ }^{\circ} \mathrm{C}$, inflammations and macrophage infiltration occurred more frequently (Fig. 1b) compared to larvae exposed at $7{ }^{\circ} \mathrm{C}$ (and the respective controls). In fish exposed at $11^{\circ} \mathrm{C}$, necrosis and fibrosis were more abundant than in fish exposed at $7{ }^{\circ} \mathrm{C}$; however, no difference between the control and venlafaxine-treated groups were detected. The liver conditions of venlafaxine-exposed juvenile brown trout ranged between category 1 and 5 . In most cases, the cytoplasm of the hepatocytes did not appear bright (Fig. 1c) and the cells were medium sized. In livers of juvenile fish exposed to 10 and $1000 \mu \mathrm{g} / \mathrm{L}$, inflammations were 


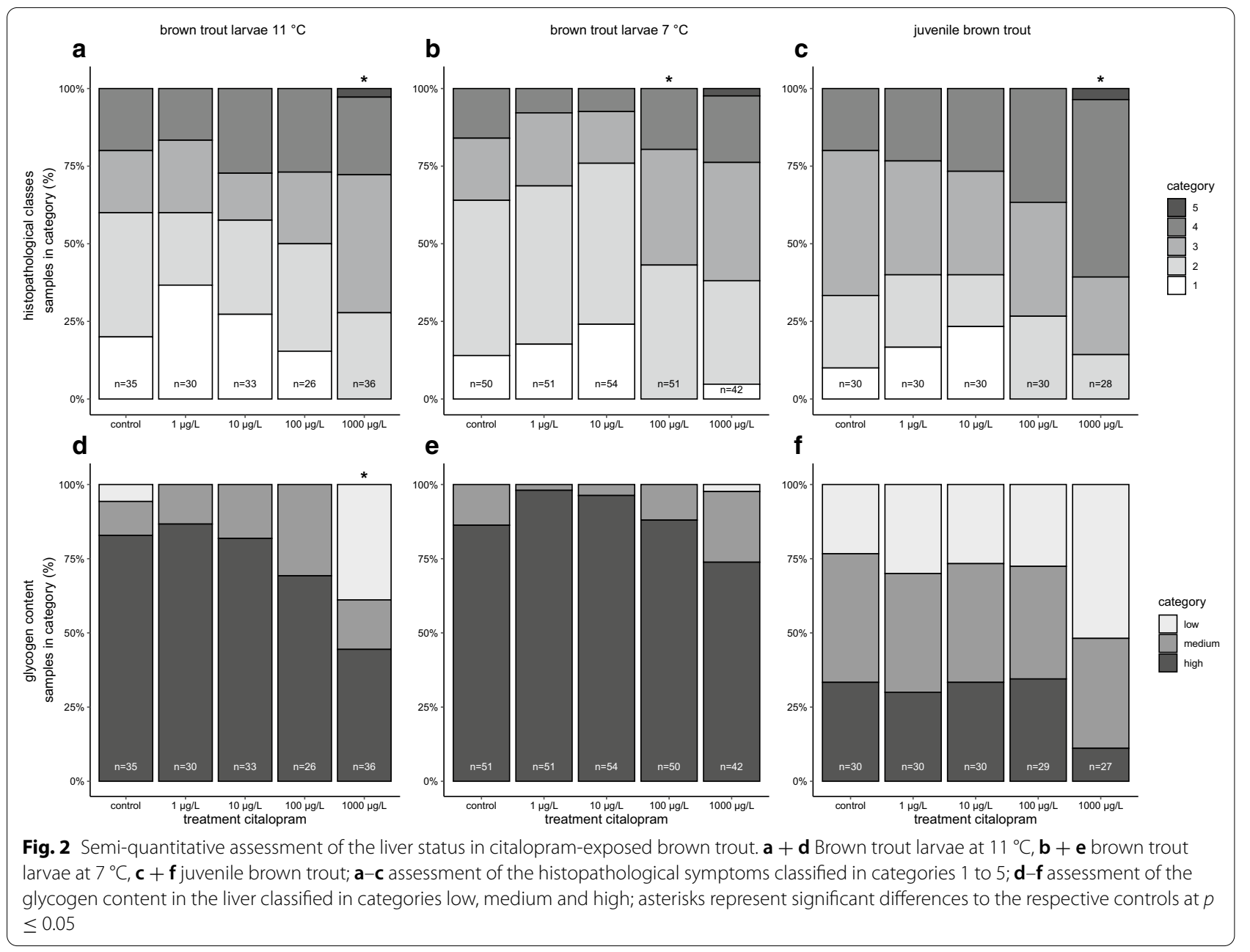

observed more frequently than in the other treatments (Fig. 1b). Dilated capillaries, intercellular spaces, vacuolisation, irregular shaped nuclei and necrosis occurred equally throughout all treatments (Fig. 1c, f). The semiquantitative assessment revealed no difference in the health status between controls and venlafaxine-exposed fish (Fig. 3) (brown trout larvae $11{ }^{\circ} \mathrm{C}$ : likelihood-ratio $\chi^{2}$ test: $d f=16, \chi^{2}=10.701, p=0.8275$; brown trout larvae $7{ }^{\circ} \mathrm{C}$ : likelihood-ratio $\chi^{2}$ test: $d f=16, \chi^{2}=15.494$, $p=0.4888$; juvenile brown trout: likelihood-ratio- $\chi^{2}$ test: $\left.d f=16, \chi^{2}=19.575, p=0.24\right)$. Likewise, the glycogen content of fish did not differ significantly from the respective controls at both temperatures (brown trout larvae $11{ }^{\circ} \mathrm{C}$ : likelihood-ratio $\chi^{2}$ test: $d f=8, X^{2}=9.941$, $p=0.2692$; brown trout larvae $7{ }^{\circ} \mathrm{C}$ : likelihood-ratio $\chi^{2}$ test: $d f=8, \chi^{2}=6.98, p=0.5388$; juvenile brown trout: likelihood-ratio $X^{2}$ test: $d f=8, X^{2}=9.911, p=0.2713$ ). However, livers of venlafaxine-exposed brown trout larvae showed a lower glycogen content than the livers from fish in all other experiments.

\section{Biochemical biomarkers}

\section{Superoxide dismutase activity}

Regarding the activity of the superoxide dismutase (SOD) in brown trout larvae exposed at $11{ }^{\circ} \mathrm{C}$ to venlafaxine, no differences between controls and chemicaltreated fish were observed (brown trout larvae $11{ }^{\circ} \mathrm{C}$ : nested ANOVA: $d f=4,10, F=1.5387, p=1946)$. However, at $7{ }^{\circ} \mathrm{C}$, the SOD activity of venlafaxine-exposed larvae was increased up to $24 \%$ in relation to the control. Brown trout larvae exposed to $10-$ and $100-\mu \mathrm{g} / \mathrm{L}$ venlafaxine at $7^{\circ} \mathrm{C}$ showed a significantly increased SOD activity compared to the respective controls, and for larvae exposed to $1000 \mu \mathrm{g} / \mathrm{L}$, the same trend became obvious (brown trout larvae $7{ }^{\circ} \mathrm{C}$ : nested ANOVA: $d f=4,10$, $F=3.7377, p=0.0064$, post hoc Dunnett's Test [control $10 \mu \mathrm{g} / \mathrm{L}] p=0.0442$, [control $\mid 100 \mu \mathrm{g} / \mathrm{L}] p=0.0048$, [control $\mid 1000 \mu \mathrm{g} / \mathrm{L}] p=0.082$ ). Comparing the SOD activity between the two temperatures, the activity in control larvae exposed at $11{ }^{\circ} \mathrm{C}(165.96 \pm 29.32 \mathrm{U} / \mathrm{mL})$ was remarkably higher (24\%) than in larvae exposed at $7{ }^{\circ} \mathrm{C}$ 

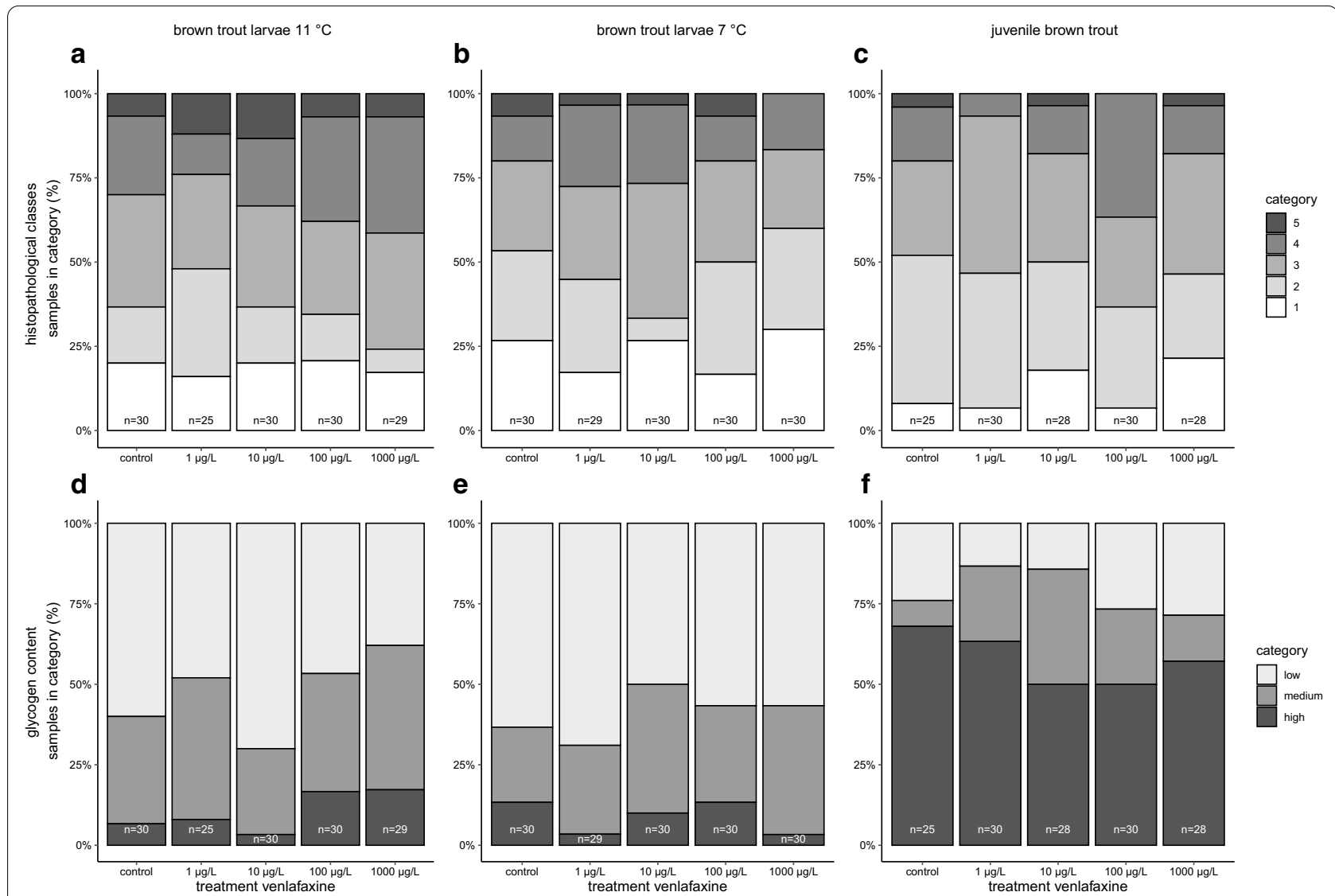

Fig. 3 Results for the semi-quantitative assessment of the liver status in venlafaxine-exposed brown trout. $\mathbf{a}+\mathbf{d}$ Brown trout larvae at $11{ }^{\circ} \mathrm{C}, \mathbf{b}$ $+\mathbf{e}$ brown trout larvae at $7^{\circ} \mathrm{C}, \mathbf{c}+\mathbf{f}$ juvenile brown trout, a-c assessment of the histopathological symptoms classified in categories 1 to 5 . $\mathbf{d}-\mathbf{f}$ Assessment of the glycogen content in the liver classified in categories low, medium and high, asterisks represent significant differences to the respective controls

$(133.86 \pm 37.49)$. Regarding the SOD activity of juvenile brown trout, the activity of fish treated with venlafaxine was on average higher than the SOD activity of control fish. The activity of the SOD in juvenile fish exposed to the highest treatment was increased by $22 \%$ compared to the respective controls; however, the difference was not statistically significant (juvenile brown trout: nested ANOVA: $d f=4,10, F=1.5804, p=0.1834)$.

\section{B-esterase activity}

The b-esterase activity did not differ between antidepressant-treated fish and the respective controls in all experiments (Tables 1, 2, 3). Thus, the b-esterase activity was neither influenced by citalopram nor venlafaxine and, furthermore, did not depend on the life stage or temperature (statistical details in Additional file 1).

\section{Stress protein level}

Hsp70 levels of juvenile brown trout were neither influenced by citalopram nor venlafaxine (Table 3) (juvenile brown trout+citalopram: nested ANOVA: $d f=4,10$, $F=1.7073, p=0.1522$; juvenile brown trout + venlafaxine: nested ANOVA: $d f=4,10, F=3.2671, p=0.0138$, post hoc Dunnett's test revealed no difference to control).

\section{Discussion}

Histopathological analyses made evident that the health status of the liver was negatively affected by citalopram in fish exposed to $100 \mu \mathrm{g} / \mathrm{L}$ or $1000 \mu \mathrm{g} / \mathrm{L}$ of the pharmaceutical. The most prominent symptoms were hyperplasia of the hepatocytes and inflammations, which occurred in larvae exposed at both temperatures, as well as in juvenile brown trout. The impaired health status of the fish liver is plausibly related to the accumulation of citalopram in the tissue of exposed fish [54] which might be responsible for an increased biotransformation activity and metabolism rate. High metabolism rates in the liver are likely reflected by a reduction of glycogen in the fish liver and hyperplasia of hepatocytes [67]. Additionally, oxidative stress could also have contributed to the depicted damages 


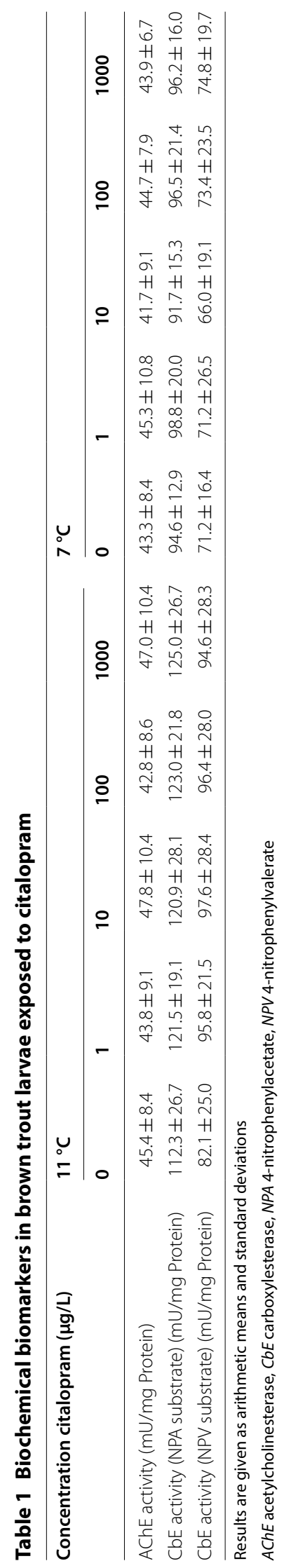



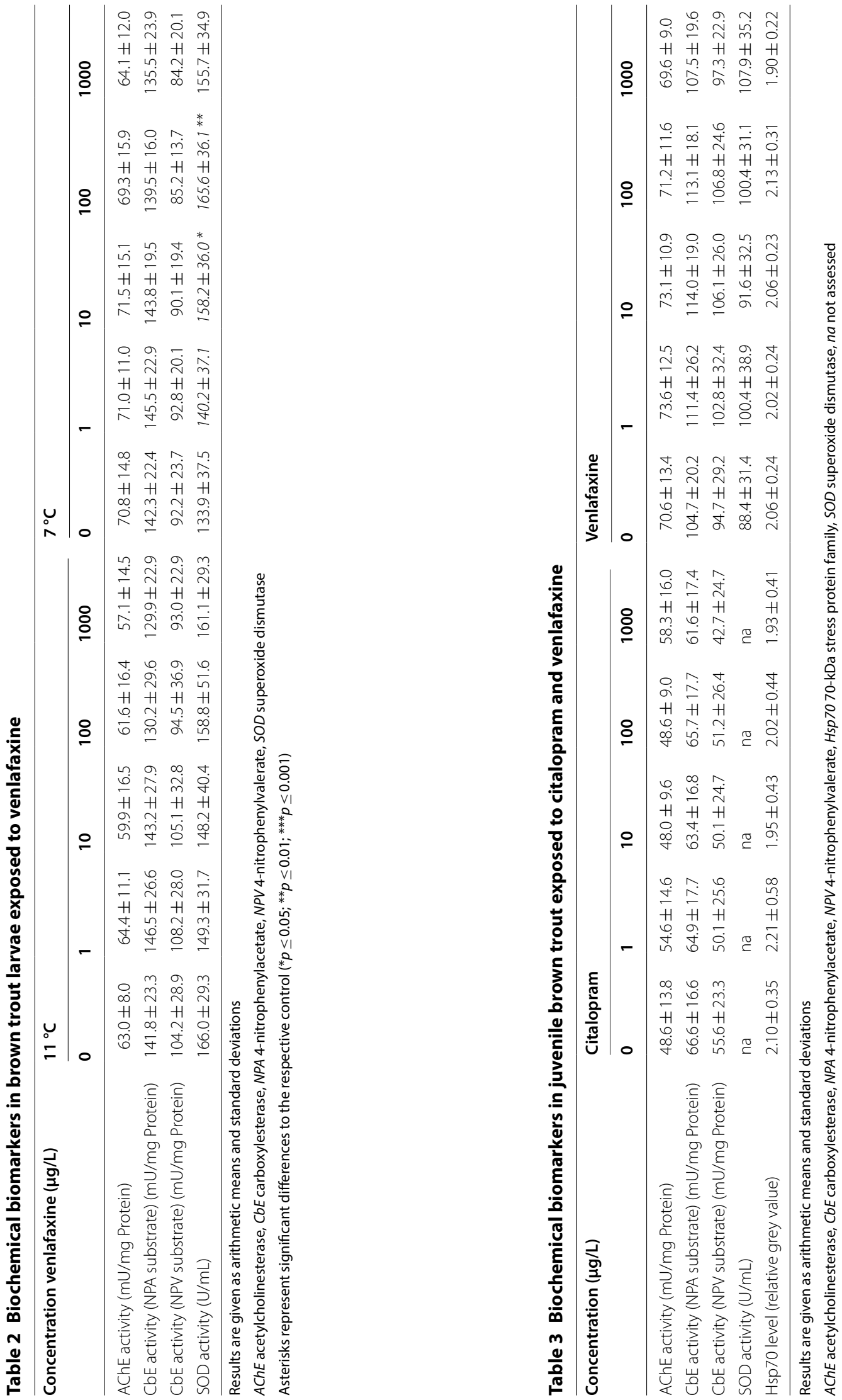
[68, 69]. According to previous studies, antidepressants in general were shown to have the potential for inducing negative effects in liver tissue. Although Schultz et al. [29] did not observe any liver alterations in response to either fluoxetine, sertraline or venlafaxine in fathead minnow, Nowakowska et al. [32], however, reported a decrease in hepatocyte proliferation in zebrafish exposed to $10 \mu \mathrm{g} / \mathrm{L}$ of the SSRIs sertraline, paroxetine and the antidepressant mianserin. Rats exposed to the SSRI fluoxetine revealed histopathological liver injury, with symptoms like, e.g., increased numbers of Kupffer and inflammatory cells as well as focal necrosis [69, 70]. Likewise, rats exposed to $20-\mathrm{mg} / \mathrm{kg}$ citalopram showed increased inflammation in their livers, higher numbers of Kupffer cells and liver lymphocytes as well as an increased activity of liver enzymes [68, 71]. Additionally, isolated rat hepatocytes exposed to $500-\mu \mathrm{M}$ citalopram showed cell death, oxidative stress and mitochondrial toxicity [68]. Also in humans, exposure to citalopram resulted in acute liver damage and increased levels of liver enzymes, indicating hepatitis [72, 73]. The observed reduction of glycogen in brown trout exposed to $1000 \mu \mathrm{g} / \mathrm{L}$ very likely went along with the observed reduced food uptake. A reduced food uptake may directly cause a decrease in glycogen storage in the liver $[74,75]$ and might be responsible for the lower growth rate in brown trout exposed to $1000-\mu \mathrm{g} / \mathrm{L}$ citalopram, compared to the controls [54].

Venlafaxine exposure did not cause severe liver damage in brown trout. Only in juveniles exposed to 10 - and $1000-\mu \mathrm{g} / \mathrm{L}$ venlafaxine, slightly more inflammations became evident than in control fish. The lacking cellular reactions in the fish livers might be due to the fact that tissue concentrations of venlafaxine were up to 500 -fold lower than those for citalopram in citalopramexposed fish [54,55], resulting in lower metabolic and biotransformation activity. Similarly, Schultz, et al. [29] did not find any evidence of venlafaxine-dependent histopathological alterations in fathead minnow livers. Furthermore, venlafaxine had no effect on the glycogen storage in the liver of exposed brown trout. Moreover, it has to be mentioned that also in control fish, slight histopathological changes became obvious which might be due to the artificial exposure conditions in the aquaria which, however, were kept as appropriate as possible during the experiments. As previously stated by [76], this might be a general physiological response of the fish to the laboratory exposure. Additionally, differences between the glycogen content between the experiments can originate from the different parental generations and the batch of eggs as well as differences in growing and between the years. Furthermore, the liver status was generally impacted by temperature. Livers of larvae exposed at $11{ }^{\circ} \mathrm{C}$ were in a worse condition with increased inflammations and necrosis than livers of larvae exposed at $7{ }^{\circ} \mathrm{C}$. The diminished health condition might be related to the higher metabolism of fish exposed at $11{ }^{\circ} \mathrm{C}$. In a study with Japanese flounder also a reduced liver health status could be shown in relation to higher temperature [77]. Additionally, data for SOD activity suggested a higher oxidative stress when exposed to the higher temperature with SOD values being $24 \%$ higher at $11^{\circ} \mathrm{C}$ than at $7{ }^{\circ} \mathrm{C}$. This difference in SOD activity might be influenced by the higher temperature of $11^{\circ} \mathrm{C}$, but differences due to different exposure time cannot be excluded. Additionally, larvae exposed at $11{ }^{\circ} \mathrm{C}$ showed a higher mortality rate compared to larvae exposed at $7{ }^{\circ} \mathrm{C}$ substantiating the poorer health condition at $11{ }^{\circ} \mathrm{C}$ [55]. The higher temperature might have increased the overall SOD activity which could possibly resulted in the worse health status and the elevated mortality. This temperature dependency is also from importance with regard to climate change. In several studies, it has become evident that oxidative stress responses are in general temperature sensitive [78-80]. Possibly, the relatively high basic level of SOD in controls at $11{ }^{\circ} \mathrm{C}$ prevented a further induction by venlafaxine, which became obvious in fish exposed at $7^{\circ} \mathrm{C}$, with more pronounced responses in larvae than in juveniles. In larvae, this effect appeared in individuals exposed to at least $10 \mu \mathrm{g} / \mathrm{L}$, with a maximum increase of $24 \%$; while, in juveniles, the maximum SOD activity was $22 \%$ higher than in the control, however not significant. Along this line, effects of different antidepressants on oxidative stress were previously published. Elevated oxidative stress indicated by changes in catalase, peroxidase, glutathione-S-transferase (GST) and SOD activity has been shown in meagre exposed to venlafaxine [28], zebrafish exposed to amitriptyline [31], goldfish exposed to sertraline [30] and daphnids exposed to citalopram [42]. In a multi-stressor experiment, temperature effects on the anti-oxidant defence have been shown and potential deleterious effects of venlafaxine on the anti-oxidant defence mechanism of zebrafish were indicated [81]. However, in one study, fluoxetine-exposed Pomatoschistus microps did not show a change in SOD activity [82]. In general, both the vast majority of literature results and our own data indicate that venlafaxine and other antidepressants can induce oxidative stress in fish.

In both life stages of brown trout, neither citalopram nor venlafaxine did alter the AChE or CbE activity; thus, no neurotoxic effect of venlafaxine or citalopram on brown trout was detected. Different enzyme activity between the years can derive from differences between the parental generation and the batch of eggs as well as growth differences between the years. Nevertheless, 
effects of antidepressants on AChE have been reported before: decreased AChE activity could be detected in a marine clam species exposed to low $\mu \mathrm{g} / \mathrm{L}$ fluoxetine [41], Pomatoschistus microps exposed to 1-mg/L fluoxetine [82] and Daphnia magna exposed to $1 \mathrm{mg} / \mathrm{L}$ citalopram [42]. In contrast, goldfish exposed to low- $\mu \mathrm{g} / \mathrm{L}$ sertraline showed an increased AChE activity, which could not be detected at higher concentrations [30]. Concerning the impact of antidepressants on carboxylesterases, to our knowledge, no data are published for fish so far.

Likewise, neither citalopram nor venlafaxine exposure induced a response of the Hsp70 system; thus, no proteotoxic effects became evident in juvenile brown trout. However, Maulvault et al. (2019) observed an increased heat shock response in meagre exposed to $20-\mu \mathrm{g} / \mathrm{L}$ venlafaxine. As Hsp70 is a rather unspecific biomarker, which is induced by various types of stressors, differences might be attributed to different exposure conditions or to species specificity.

Generally, with climate change in mind, temperature plays an important role in our scenarios, because it can have an impact on many physiological responses in fish [77, 79-81]. We could see that fish exposed at $11{ }^{\circ} \mathrm{C}$ revealed an overall higher SOD activity; however, differences between larvae exposed at $11^{\circ} \mathrm{C}$ and $7{ }^{\circ} \mathrm{C}$ cannot solely be attributed to temperature effects, because of different exposure times. Furthermore, it could be shown that effects in larvae were more pronounced than in juveniles; however, these differences can also not solely be accredited to different sensitivities of the life stages but can also result from longer exposure times of larvae. A comparison of the presented biomarker data with previously published results obtained for endpoints like behaviour and growth impairment from the same experiments [54, 55] makes evident that the effect concentrations for behavioural and growth effects are in the same range as those for the biomarker responses shown here. The lowest observed effect concentration (LOEC) in citalopram-exposed brown trout was $100 \mu \mathrm{g} / \mathrm{L}$ reflected by histopathological as well as behavioural alterations. Similarly, in venlafaxine-exposed brown trout, behavioural and growth endpoints show similar LOECs of $10 \mu \mathrm{g} / \mathrm{L}$ as the biochemical biomarker SOD activity. This demonstrates that citalopram and venlafaxine can induce effects on cellular and biochemical markers in equivalent concentrations as it affects growth and behavioural endpoints. As a result, the no-observed-effect concentrations (NOEC) in these experiments are just an order of magnitude above environmentally relevant concentrations and, thus, reasonably call for increased vigilance towards these pharmaceuticals in the environment.

\section{Conclusion}

Combining the results for histopathology, neurotoxicity, proteotoxicity and oxidative stress with previously published data, it became evident that effects and side effects of citalopram and venlafaxine in brown trout are similar to those known for humans. LOECs were at $10 \mu \mathrm{g} / \mathrm{L}$ for venlafaxine and at $100 \mu \mathrm{g} / \mathrm{L}$ for citalopram, matching LOECs previously recorded for behavioural and growth endpoints. Although the NOECs for citalopram and venlafaxine are at least a decimal power higher than environmentally relevant concentrations, in consideration of safety factors and additive effects, both antidepressants have necessarily to be considered in environmental risk assessment.

\section{Supplementary Information}

The online version contains supplementary material available at https://doi. org/10.1186/s12302-020-00437-z.

Additional file 1. Biochemical and cellular biomarkers in brown trout (Salmo trutta f. fario) in response to the antidepressants citalopram and venlafaxine.

\section{Acknowledgements}

The authors thank the Ministry of Science, Research and Arts Baden-Württemberg for funding the Water Research Network Baden-Württemberg (Wassernetzwerk Baden-Württemberg), in which the Effect-Net (Effect Network in Water Research) project is embedded. Particular thanks go to our project coordinator, Thomas Braunbeck. Furthermore, we want to thank Stefanie Jacob, Stefanie Krais, Elisabeth May, Katharina Peschke, Hannah Schmieg and Sabrina Wilhelm for laboratory support and technical assistance. Thanks also go to Stefanie Dietz and Mona Schweizer for constructive comments on the manuscript.

\section{Authors' contributions}

MZ conceived, designed and performed the experiments, analysed the data and prepared the figures and tables and wrote the first draft of the paper and edited according to the coauthors. HE, SO, LR and SS analysed part of the Data and approved the final draft. H-RK and RT conceived and designed the experiments and contributed reagents/materials/analysis tools as well as reviewed the first draft of the paper and approved the final draft. All authors read and approved the final manuscript.

\section{Funding}

Open Access funding enabled and organized by Projekt DEAL. This study is part of the Effect-Net project (Effect Network in Water Research), which is part of the Water Research Network Baden-Württemberg (Wassernetzwerk Baden-Württemberg) and is funded by the Ministry of Science, Research and Arts of Baden-Württemberg. The authors received support from the Open Access Publishing Fund of University of Tübingen. The funders had no role in study design, data collection and analysis, decision to publish, or preparation of the manuscript.

\section{Availability of data and materials}

The datasets generated and/or analysed during the current study are available in the effectnet-seek repository, https://effectnet-seek.bioquant.uni-heide lberg.de/investigations/9.

\section{Ethics approval}

All animals were approved by the animal welfare committee of the Regional Council of Tübingen, Germany (ZO 2/16).

Consent for publication

Not applicable. 


\section{Competing interests}

The authors declare that they have no competing interests.

\section{Author details}

${ }^{1}$ Animal Physiological Ecology, University of Tübingen, Auf der Morgenstelle 5, 72076 Tübingen, Germany. ${ }^{2}$ Steinbeis Transfer Center for Ecotoxicology and Ecophysiology, Blumenstraße 13, 72108 Rottenburg, Germany.

Received: 11 October 2020 Accepted: 27 November 2020 Published online: 16 December 2020

\section{References}

1. Liu Q, He H, Yang J, Feng X, Zhao F, Lyu J (2020) Changes in the global burden of depression from 1990 to 2017: findings from the Global Burden of Disease study. J Psychiatr Res 126:134-140. https://doi. org/10.1016/j.jpsychires.2019.08.002

2. Wittchen HU, Jacobi F, Rehm J, Gustavsson A, Svensson M, Jonsson B, Olesen J, Allgulander C, Alonso J, Faravelli C, Fratiglioni L, Jennum P, Lieb R, Maercker A, van Os J, Preisig M, Salvador-Carulla L, Simon R, Steinhausen HC (2010) The size and burden of mental disorders and other disorders of the brain in Europe. Eur Neuropsychopharmacol 21(9):655-679. https://doi.org/10.1016/j.euroneuro.2011.07.018

3. Schwabe U, Paffrath D, Ludwig W-D, Klauber J (2019) Arzneiverordnungsreport 2019. Springer-Verlag GmbH, Berlin

4. Bezchlibnyk-Butler K, Aleksic I, Kennedy SH (2000) Citalopram - a review of pharmacological and clinical effects. J Psychiatry Neurosci 25(3):241-254

5. Holliday SM, Benfield P (1995) Venlafaxine: a review of its pharmacology and therapeutic potential in depression. Drugs 49(2):280-294. https://doi. org/10.2165/00003495-199549020-00010

6. Burnett F, Dinan TG (1998) Venlafaxine. Pharmacology and therapeutic potential in the treatment of depression, human psychopharmacology 13:153-162. https://doi.org/10.1002/(SICI)1099-1077(199804)13:3\%3c153 :AID-HUP973\%3e3.0.CO;2-S

7. Mackulak T, Mosny M, Skubak J, Grabic R, Birosova L (2015) Fate of psychoactive compounds in wastewater treatment plant and the possibility of their degradation using aquatic plants. Environ Toxicol Pharmacol 39(2):969-973. https://doi.org/10.1016/j.etap.2015.02.018

8. Noble S, Benfield P (1997) Citalopram. CNS Drugs 8(5):410-431. https:// doi.org/10.2165/00023210-199708050-00009

9. Golovko O, Kumar V, Fedorova G, RandakT, Grabic R (2014) Seasonal changes in antibiotics, antidepressants/psychiatric drugs, antihistamines and lipid regulators in a wastewater treatment plant. Chemosphere 111:418-426. https://doi.org/10.1016/j.chemosphere.2014.03.132

10. Lajeunesse A, Smyth SA, Barclay K, Sauve S, Gagnon C (2012) Distribution of antidepressant residues in wastewater and biosolids following different treatment processes by municipal wastewater treatment plants in Canada. Water Res 46(17):5600-5612. https://doi.org/10.1016/j.watre s.2012.07.042

11. Ferrer I, Thurman EM (2012) Analysis of 100 pharmaceuticals and their degradates in water samples by liquid chromatography/quadrupole time-of-flight mass spectrometry. J Chromatogr A 1259:148-157. https:// doi.org/10.1016/j.chroma.2012.03.059

12. Fick J, Söderström H, Lindberg RH, Phan C, Tysklind M, Larsson DGJ (2009) Contamination of surface, ground, and drinking water from pharmaceutical production. Environ Toxicol Chem 28(12):2522-2527. https://doi. org/10.1897/09-073.s1

13. Grabicova K, Grabic R, Fedorova G, Fick J, Cerveny D, Kolarova J, Turek J, Zlabek V, RandakT (2017) Bioaccumulation of psychoactive pharmaceuticals in fish in an effluent dominated stream. Water Res 124:654-662. https ://doi.org/10.1016/j.watres.2017.08.018

14. Himmelsbach M, Buchberger W, Klampfl CW (2006) Determination of antidepressants in surface and waste water samples by capillary electrophoresis with electrospray ionization mass spectrometric detection afte preconcentration using off-line solid-phase extraction. Electrophoresis 27(5-6):1220-1226. https://doi.org/10.1002/elps.200500693

15. Lajeunesse A, Gagnon C, Sauvé S (2008) Determination of basic antidepressants and their $\mathrm{N}$-desmethyl metabolites in raw sewage and wastewater using solid-phase extraction and liquid chromatography-tandem mass spectrometry. Anal Chem (Washington) 80(14):5325-5333. https:// doi.org/10.1021/ac800162q

16. Nodler K, Licha T, Bester K, Sauter M (2010) Development of a multiresidue analytical method, based on liquid chromatography-tandem mass spectrometry, for the simultaneous determination of 46 microcontaminants in aqueous samples. J Chromatogr A 1217(42):6511-6521. https://doi.org/10.1016/j.chroma.2010.08.048

17. Schultz MM, Furlong ET, Kolpin DW, Werner SL, Schoenfuss HL, Barber LB, Blazer VS, Norris DO, Vajda AM (2010) Antidepressant pharmaceuticals in two US effluent-impacted streams: occurrence and fate in water and sediment, and selective uptake in fish neural tissue. Environ Sci Technol 44:1918-1925. https://doi.org/10.1021/es9022706

18. Silva L, Pereira AM, Meisel LM, Lino CM, Pena A (2014) A one-year follow-up analysis of antidepressants in Portuguese wastewaters: occurrence and fate, seasonal influence, and risk assessment. Sci Total Environ 490:279-287. https://doi.org/10.1016/j.scitotenv.2014.04.131

19. Larsson DG, de Pedro C, Paxeus N (2007) Effluent from drug manufactures contains extremely high levels of pharmaceuticals. J Hazard Mater 148(3):751-755. https://doi.org/10.1016/j.jhazmat.2007.07.008

20. Brodin T, Piovano S, Fick J, Klaminder J, Heynen M, Jonsson M (2014) Ecological effects of pharmaceuticals in aquatic systems-impacts through behavioural alterations. Philos Trans R Soc London B Biol Sci. https://doi. org/10.1098/rstb.2013.0580

21. Sehonova P, Svobodova Z, Dolezelova P, Vosmerova P, Faggio C (2018) Effects of waterborne antidepressants on non-target animals living in the aquatic environment: a review. Sci Total Environ 631-632:789-794. https ://doi.org/10.1016/j.scitotenv.2018.03.076

22. Melvin SD (2017) Effect of antidepressants on circadian rhythms in fish: insights and implications regarding the design of behavioural toxicity tests. Aquat Toxicol 182:20-30. https://doi.org/10.1016/j.aquat ox.2016.11.007

23. Painter MM, Buerkley MA, Julius ML, Vajda AM, Norris DO, Barber LB, Furlong ET, Schultz MM, Schoenfuss HL (2009) Antidepressants at Environmentaly Relevant Concentrations affect Predator Avoidance Behavior of Larval Fathead Minnows (Pimephales promelas). Environ Toxicol Chem 28(12):2677-2684. https://doi.org/10.1897/08-556.1

24. Kellner M, Porseryd T, Porsch-Hallstrom I, Hansen SH, Olsen KH (2015) Environmentally relevant concentrations of citalopram partially inhibit feeding in the three-spine stickleback (Gasterosteus aculeatus). Aquat Toxicol 158:165-170. https://doi.org/10.1016/j.aquatox.2014.11.003

25. Kellner M, Porseryd T, Porsch-Hallstrom I, Borg B, Roufidou C, Olsen KH (2017) Developmental exposure to the SSRI citalopram causes longlasting behavioural effects in the three-spined stickleback (Gasterosteus aculeatus). Ecotoxicology 27(1):12-22. https://doi.org/10.1007/s1064 6-017-1866-4

26. Maulvault AL, Santos $L$, Paula JR, Camacho C, Pissarra V, Fogaca F, Barbosa V, Alves R, Ferreira PP, Barcelo D, Rodriguez-Mozaz S, Marques A, Diniz $M$, Rosa R (2018) Differential behavioural responses to venlafaxine exposure route, warming and acidification in juvenile fish (Argyrosomus regius). Sci Total Environ 634:1136-1147. https://doi.org/10.1016/j.scito tenv.2018.04.015

27. Kellner M, Porseryd T, Hallgren S, Porsch-Hallstrom I, Hansen SH, Olsen KH (2016) Waterborne citalopram has anxiolytic effects and increases locomotor activity in the three-spine stickleback (Gasterosteus aculeatus). Aquat Toxicol 173:19-28. https://doi.org/10.1016/j.aquatox.2015.12.026

28. Maulvault AL, Camacho C, Barbosa V, Alves R, Anacleto P, Pousao-Ferreira P, Rosa R, Marques A, Diniz MS (2019) Living in a multi-stressors environment: an integrated biomarker approach to assess the ecotoxicological response of meagre (Argyrosomus regius) to venlafaxine, warming and acidification. Environ Res 169:7-25. https://doi.org/10.1016/j.envre s.2018.10.021

29. Schultz MM, Painter MM, Bartell SE, Logue A, Furlong ET, Werner SL, Schoenfuss HL (2011) Selective uptake and biological consequences of environmentally relevant antidepressant pharmaceutical exposures on male fathead minnows. Aquatic Toxicol 104(1-2):38-47. https://doi. org/10.1016/j.aquatox.2011.03.011

30. Xie Z, Lu G, Li S, Nie Y, Ma B, Liu J (2015) Behavioral and biochemical responses in freshwater fish Carassius auratus exposed to sertraline. Chemosphere 135:146-155. https://doi.org/10.1016/j.chemospher e.2015.04.031 
31. Yang M, Qiu W, Chen J, Zhan J, Pan C, Lei X, Wu M (2014) Growth inhibition and coordinated physiological regulation of zebrafish (Danio rerio) embryos upon sublethal exposure to antidepressant amitriptyline. Aquat Toxicol 151:68-76. https://doi.org/10.1016/j.aquatox.2013.12.029

32. Nowakowska K, Giebultowicz J, Kamaszewski M, Adamski A, Szudrowicz H, Ostaszewska T, Solarska-Dzieciolowska U, Nalecz-Jawecki G, Wroczynski P, Drobniewska A (2020) Acute exposure of zebrafish (Danio rerio) larvae to environmental concentrations of selected antidepressants: Bioaccumulation, physiological and histological changes. Comparative Biochem Physiol 229:108670. https://doi.org/10.1016/j.cbpc.2019.108670

33. Rey Vazquez G, Da Cuna RH, Dorelle LS, Lo Nostro FL (2020) Immunohistological Biomarkers of Toxicity by a Pharmaceutical Antidepressant in the Freshwater Cichlid Fish Cichlasoma dimerus (Teleostei, Cichliformes). Bull Environ Contamin Toxicol 104(2):180-184. https://doi.org/10.1007/ s00128-019-02770-3

34. Dußling U, Berg R (2001) Fische in Baden-Württemberg. Ministry for Food and Agriculture Baden-Württemberg, Stuttgart

35. Klemetsen A, Amundsen P-A, Dempson JB, Jonsson B, Jonsson N O'Conell MF, Mortensen E (2003) Atlantic salmon Salmo salar L, brown trout Salmo trutta $\mathrm{L}$ and Arctic charr Salvelinus alpinus ( $\mathrm{L})$ : a review of aspects of their life histories. Ecol Freshw Fish 12:1-59. https://doi.org/10. 1034/j.1600-0633.2003.00010.x

36. Aldridge WN (1952) Serum Esterases 1 Two types of esterase (A and B) hydrolysing $\mathrm{p}$-nitrophenyl acetate, propionate and butyrate, and a method for their determination. Biochem J 1:110-117. https://doi. org/10.1042/bj0530110

37. Laguerre C, Sanchez-Hernandez JC, Kohler HR, Triebskorn R, Capowiez Y, Rault M, Mazzia C (2009) B-type esterases in the snail Xeropicta derbentina: an enzymological analysis to evaluate their use as biomarkers of pesticide exposure. Environ Pollut 157(1):199-207. https://doi.org/10.1016/j.envpo I.2008.07.003

38. Rault M, Collange B, Mazzia C, Capowiez Y (2008) Dynamics of acetylcholinesterase activity recovery in two earthworm species following exposure to ethyl-parathion. Soil Biol Biochem 40(12):3086-3091. https:// doi.org/10.1016/j.soilbio.2008.09.010

39. Carr RL, Chambers JE (1991) Acute effects of the organophosphate paraoxon on schedule-controlled behavior and esterase activity in rats: dose-response relationships. Pharmacol Biochem Behav 40:929-936. https://doi.org/10.1016/0091-3057(91)90108-E

40. Sanchez-Hernandez JC, Mazzia C, Capowiez Y, Rault M (2009) Carboxylesterase activity in earthworm gut contents: Potential (eco)toxicological implications. Comparative Biochem Physiol 150(4):503-511. https://doi. org/10.1016/j.cbpc.2009.07.009

41. Munari M, Marin MG, Matozzo V (2014) Effects of the antidepressant fluoxetine on the immune parameters and acetylcholinesterase activity of the clam Venerupis philippinarum. Marine Environ Res 94:32-37. https:// doi.org/10.1016/j.marenvres.2013.11.007

42. Yang H, Lu G, Yan Z, Liu J, Ma B, Dong H (2017) Biological effects of citalopram in a suspended sediment-water system on Daphnia magna. Environ Sci Pollut Res Int 24(26):21180-21190. https://doi.org/10.1007/ s11356-017-9763-1

43. Regoli F, Giuliani ME (2014) Oxidative pathways of chemical toxicity and oxidative stress biomarkers in marine organisms. Marine Environ Res 93:106-117. https://doi.org/10.1016/j.marenvres.2013.07.006

44. Pedrajas JR, Peinado J, López-Barea J (1995) Oxidative stress in fish exposed to model xenobiotics, Oxidatively modified forms of $\mathrm{Cu}$, Zn-superoxide dismutase as potential biomarkers. Chemico-Biological Interactions 98:16. https://doi.org/10.1016/0009-2797(95)03651-2

45. Vutukuru SS, Chintada S, RadhaMadhavi K, VenkateswaraRao J, Anjaneyulu Y (2006) Acute effects of copper on superoxide dismutase, catalase and lipid peroxidation in the freshwater teleost fish, Esomus danricus. Fish Physiol Biochem 32(3):221-229. https://doi.org/10.1007/ s10695-006-9004-X

46. Valavanidis A, Vlahogianni T, Dassenakis M, Scoullos M (2006) Molecular biomarkers of oxidative stress in aquatic organisms in relation to toxic environmental pollutants. Ecotoxicol Environ Saf 64(2):178-189. https:// doi.org/10.1016/j.ecoenv.2005.03.013

47. Feder ME, Hofmann GE (1999) Heat-shock proteins, molecular chaperones, and the stress response: evolutionary and ecological physiology. Annu Rev Physiol 61:243-282. https://doi.org/10.1146/annurev.physi ol.61.1.243
48. Fink AL (1999) Chaperone-mediated protein folding. Physiol Rev 79(2):425-449

49. Köhler H-R, Bartussek C, Eckwert H, Farian K, Gränzer S, Knigge T, Kunz N (2001) The hepatic stress protein (hsp70) response to interacting abiotic parameters in fish exposed to various levels of pollution. J Aqu Ecosyst Stress Recov 8:261-279. https://doi.org/10.1023/A:1012935931161

50. Rodriguez EDL, Fanta E (1998) Liver Histopathology of the Fish Brachydanio rerio Hamilton-Buchman after Acute Exposure to Sublethal Levels of the Organophosphate Dimethoate 500. Revista Brasileira de Zoologia 15(2):441-450. https://doi.org/10.1590/s0101-81751998000200014

51. Bernet D, Schmidt H, Meier W, Burkhardt-Holm P, Wahli T (1999) Histopathology in fish: proposal for a protocol to assess aquatic pollution. J Fish Dis 22:25-34. https://doi.org/10.1046/j.1365-2761.1999.00134.x

52. Jacob S, Knoll S, Huhn C, Kohler HR, Tisler S, Zwiener C, Triebskorn R (2019) Effects of guanylurea, the transformation product of the antidiabetic drug metformin, on the health of brown trout (Salmo trutta f fario). Peer J 7:e7289. https://doi.org/10.7717/peerj.7289

53. Triebskorn R, Casper H, Scheil V, Schwaiger J (2007) Ultrastructural effects of pharmaceuticals (carbamazepine, clofibric acid, metoprolol, diclofenac) in rainbow trout (Oncorhynchus mykiss) and common carp (Cyprinus carpio). Anal Bioanal Chem 387(4):1405-1416. https://doi. org/10.1007/s00216-006-1033-x

54. Ziegler M, Knoll S, Köhler H-R, Tisler S, Huhn C, Zwiener C, Triebskorn R (2020) Impact of the antidepressant citalopram on the behaviour of two different life stages of brown trout. PeerJ. https://doi.org/10.7717/ peerj.8765

55. Ziegler M, Banet M, Bauer R, Köhler H-R, Stepinski S, Tisler S, Huhn C, Zwiener C, Triebskorn R (2020) Behavioural and developmental changes in brown trout after exposure to venlafaxine. Manuscript, in preparation, contact: michael.ziegler@student.uni-tuebingen.de

56. EU (2006) Richtlinie 2006/88/EG des Rates mit Gesundheits- und Hygienevorschriften für Tiere in Aquakultur und Aquakulturerzeignissen und zur Verhühtung und Bekämpfung bestimmter Wassertierkrankheiten, Amtsblatt der Europäischen Union L 328/14, Luxemburg

57. Bradford MM (1976) A rapid and sensitive method for the quantitation of microgram quantities of protein utilizing the principle of proteindye binding. Anal Biochem 72:248-254. https://doi.org/10.1016/00032697(76)90527-3

58. Triebskorn R, Telcean I, Casper H, Farkas A, Sandu C, Stan G, Colarescu O, Dori T, Kohler HR (2008) Monitoring pollution in River Mures, Romania, part II: metal accumulation and histopathology in fish. Environ Monit Assessment 141(1-3):177-188. https://doi.org/10.1007/s1066 1-007-9886-9

59. Lowry OH, Rosebrough NJ, Farr AL, Randall RJ (1951) Protein measurement with the folin phenol reagent. J Biol Chem pp 265-275; ISSN: 0021-9258

60. Markwell MAK, Haas SM, Bieber LL, Tolbert NE (1978) A modification of the lowry procedure to simplify protein determination in membrane and lipoprotein samples. Anal Biochem 87:206-210. https://doi. org/10.1016/0003-2697(78)90586-9

61. Ellman GL, Courtney KD, Andres V, Featherstone RM (1961) A new and rapid colorimetric determination of acetylcholinesterase activity. Biochem Pharmacol 7:88-95. https://doi.org/10.1016/0006-2952(61)90145 $-9$

62. Šinko G, Čalić M, Bosak A, Kovarik Z (2007) Limitation of the Ellman method: Cholinesterase activity measurement in the presence of oximes. Anal Biochem 370(2):223-227. https://doi.org/10.1016/j. ab.2007.07.023

63. Chanda MS, Mortensen SR, Moser VC, Padilla S (1997) Tissue-specific effects of chlorpyrifos on carboxylesterase and cholinesterase activity in adult rats: an in vitro and in vivo comparison. Fund Appl Nematol 38(2):148-157. https://doi.org/10.1093/toxsci/38.2.148

64. Jacob S, Dotsch A, Knoll S, Kohler HR, Rogall E, Stoll D, Tisler S, Huhn C, Schwartz T, Zwiener C, Triebskorn R (2018) Does the antidiabetic drug metformin affect embryo development and the health of brown trout (Salmo trutta f fario)? Environ Sci Eur 30(1):48. https://doi.org/10.1186/ s12302-018-0179-4

65. Dieterich A, Troschinski S, Schwarz S, Di Lellis MA, Henneberg A, Fischbach U, Ludwig M, Gartner U, Triebskorn R, Kohler HR (2015) Hsp70 and lipid peroxide levels following heat stress in Xeropicta derbentina (Krynicki 1836) (Gastropoda, Pulmonata) with regard to different colour morphs. 
Cell Stress Chaperones 20(1):159-168. https://doi.org/10.1007/s1219 2-014-0534-3

66. Benjamini Y, Hochberg Y (1995) Controlling the false discovery rate: a practical and powerful approach to multiple testing. J R Stat Soc 57(1):12. https://doi.org/10.2307/2346101

67. Spina E, Santoro V, D'Arrigo C (2008) Clinically relevant pharmacokinetic drug interactions with second-generation antidepressants: an update. Clin Ther 30(7):1206-1227. https://doi.org/10.1016/j.clinthera.2008.07.009

68. Ahmadian E, Eftekhari A, Fard JK, Babaei H, Nayebi AM, Mohammadnejad D, Eghbal MA (2017) In vitro and in vivo evaluation of the mechanisms of citalopram-induced hepatotoxicity. Arch Pharm Res 40(11):1296-1313. https://doi.org/10.1007/s12272-016-0766-0

69. Zlatkovic J, Todorovic N, Tomanovic N, Boskovic M, Djordjevic S, LazarevicPasti T, Bernardi RE, Djurdjevic A, Filipovic D (2014) Chronic administration of fluoxetine or clozapine induces oxidative stress in rat liver: a histopathological study. Eur J Pharm Sci 59:20-30. https://doi.org/10.1016/j. ejps.2014.04.010

70. Özden H, Bildirici K, Üstüner D, Cengis BP, Tülay A, Yilmaz V (2005) Histopathological examination of rat liver after experimental application of fluoxetine. Türkiye Ekopatoloji Dergisi 11(1):9-15

71. Mohammadi Z, Azarnia M, Mirabolghasemi G, Shiravi A, Mohammadi Z (2013) Histological changes in the liver of fetuses of pregnant rats following citalopram administration. Indian J Pharmacol 45(5):517-521. https:// doi.org/10.4103/0253-7613.117726

72. Hunfeld NGM, ten Berge RL, LeBrun PPH, Smith SJ, Melief PHGJ (2010) Hepatotoxicity related to citalopram intake: a case report. Int J Risk Saf Med 22(1):1-5. https://doi.org/10.3233/jrs-2010-0486

73. Neumann H, Csepregi A, Evert M, Malfertheiner P (2008) Drug-induced liver disease related to citalopram. J Clin Psychopharmacol 28(2):254-255. https://doi.org/10.1097/jcp.0b013e318167b8e1

74. Driedzic WR, Short CE (2007) Relationship between food availability, glycerol and glycogen levels in low-temperature challenged rainbow smelt Osmerus mordax. J Exp Biol 210(Pt 16):2866-2872. https://doi. org/10.1242/jeb.003749

75. Vijayan MM, Moon TW (1992) Acute handling stress alters hepatic glycogen metabolism in food-deprived rainbow-trout (Oncorhynchus mykiss). Can J Fish Aquatic Sci 49(11):7. https://doi.org/10.1139/f92-247
76. Schwarz S, Schmieg H, Scheurer M, Kohler HR, Triebskorn R (2017) Impact of the NSAID diclofenac on survival, development, behaviour and health of embryonic and juvenile stages of brown trout, Salmo trutta ffario. Sci Total Environ 607-608:1026-1036. https://doi.org/10.1016/j.scito tenv.2017.07.042

77. Liu Y, Ma D, Xiao Z, Xu S, Wang Y, Wang Y, Xiao Y, Song Z, Teng Z, Liu Q, Li J (2014) Histological change and heat shock protein 70 expression in different tissues of Japanese flounder Paralichthys olivaceus in response to elevated temperature. Chin J Oceanol Limnol 33(1):11-19. https://doi. org/10.1007/s00343-015-4028-7

78. Birnie-Gauvin K, Costantini D, Cooke SJ, Willmore WG (2017) A comparative and evolutionary approach to oxidative stress in fish: A review. Fish Fisheries 18(5):928-942. https://doi.org/10.1111/faf.12215

79. Madeira D, Narciso L, Cabral HN, Vinagre C, Diniz MS (2013) Influence of temperature in thermal and oxidative stress responses in estuarine fish. Comparative Biochem Physiol 166(2):237-243. https://doi.org/10.1016/j. cbpa.2013.06.008

80. Vinagre C, Madeira D, Narciso L, Cabral HN, Diniz M (2012) Effect of temperature on oxidative stress in fish: lipid peroxidation and catalase activity in the muscle of juvenile seabass. Dicentrarchus labrax, Ecological Indicators 23:274-279. https://doi.org/10.1016/j.ecolind.2012.04.009

81. Mehdi H, Bragg LM, Servos MR, Craig PM (2019) Multiple stressors in the environment: the effects of exposure to an antidepressant (Venlafaxine) and Increased Temperature on Zebrafish Metabolism. Front Physiol 10:1431. https://doi.org/10.3389/fphys.2019.01431

82. Duarte IA, Pais MP, Reis-Santos P, Cabral HN, Fonseca VF (2019) Biomarker and behavioural responses of an estuarine fish following acute exposure to fluoxetine. Marine Environ Res 147:24-31. https://doi.org/10.1016/j. marenvres.2019.04.002

\section{Publisher's Note}

Springer Nature remains neutral with regard to jurisdictional claims in published maps and institutional affiliations.

\section{Submit your manuscript to a SpringerOpen ${ }^{\circ}$ journal and benefit from:}

- Convenient online submission

- Rigorous peer review

- Open access: articles freely available online

- High visibility within the field

Retaining the copyright to your article

Submit your next manuscript at $\boldsymbol{\nabla}$ springeropen.com 